\title{
D-chiro-inositol, an aromatase down- modulator, increases androgens and reduces estrogens in male volunteers: a pilot study
}

Giovanni Monastra ${ }^{1,2}$, Mónica Vazquez-Levin ${ }^{3,2}$, Maria Salome Bezerra Espinola ${ }^{1,2,4}$, Gabriele Bilotta4, Antonio Simone Laganà ${ }^{5,2}$ and Vittorio Unfer ${ }^{1,2^{*}}$ (D)

\begin{abstract}
Background: Androgen deficiency affects men in the adulthood, causing several harmful effects at the reproductive and behavioural levels. Since aromatase is an enzyme that catalyses the conversion of androgens to estrogens, and it is responsible for an adequate balance of both sex hormones in males and females, the administration of molecules acting as down modulators may contribute to restore an abnormal enzymatic activity. A prospective pilot study was carried out to investigate the effect of D-chiro-inositol, a putative aromatase downmodulator, on serum levels of testosterone, estradiol, estrone, dehydroepiandrosterone and epiandrosterone from a group of adult male volunteers. Glucose, insulin, follicle-stimulating hormone, luteinizing hormone, inhibin B, Dchiro-inositol and myo-inositol serum levels were also measured.

Results: Male volunteers were selected according to age and body mass index. Subjects with altered glycemia and/or hormonal status, due to advanced age or abnormal weight, were enrolled in the study. Each of the 10 volunteers enrolled took oral D-chiro-inositol (1 g/day) for 1 month. Serum assays of selected markers were performed at baseline (control) and after treatment. D-chiro-inositol administration was associated to reduced serum levels of estrone $(-85.0 \%)$ and estradiol $(-14.4 \%)$, and increased serum levels of testosterone $(+23.4 \%)$ and dehydroepiandrosterone (+13.8\%). In addition, epiandrosterone levels were higher (+39\%) after treatment. On the other hand, follicle-stimulating hormone, luteinizing hormone and inhibin B did not change. A trend toward a decrease of glycemia, insulinemia and Homeostatic Model Assessment index was observed after D-chiro-inositol treatment, although differences did not reach statistical significance. D-chiro-inositol treatment did not cause any noticeable adverse effect.

\footnotetext{
*Correspondence: vunfer@gmail.com

'Systems Biology Group Lab, Rome, Italy

2Experts Group on Inositols in Basic and Clinical Research (EGOI), Rome, Italy

Full list of author information is available at the end of the article
}

C C The Author(s). 2021 Open Access This article is licensed under a Creative Commons Attribution 4.0 International License, which permits use, sharing, adaptation, distribution and reproduction in any medium or format, as long as you give appropriate credit to the original author(s) and the source, provide a link to the Creative Commons licence, and indicate if changes were made. The images or other third party material in this article are included in the article's Creative Commons licence, unless indicated otherwise in a credit line to the material. If material is not included in the article's Creative Commons licence and your intended use is not permitted by statutory regulation or exceeds the permitted use, you will need to obtain permission directly from the copyright holder. To view a copy of this licence, visit http://creativecommons.org/licenses/by/4.0/ The Creative Commons Public Domain Dedication waiver (http://creativecommons.org/publicdomain/zero/1.0/) applies to the data made available in this article, unless otherwise stated in a credit line to the data. 
(Continued from previous page)

Conclusions: Increased androgens and decreased estrogens seem to confirm that D-chiro-inositol acts as an aromatase down-modulator, but with a still unknown mechanism of action. This pilot study opens up new perspectives of research and therapeutic applications for D-chiro-inositol at different dosages and length of treatment.

Authorization number 005/2020 released by the Local Ethics Committee of Alma Res Fertility Center, Rome.

Trial registration number: NCT04615767 (registry: ClinicalTrials.gov)

Date of registration: November 3, 2020

Keywords: DHEAS, Epiandrosterone, Estradiol, Estrone, Glycemia, HOMA index, Inhibin B, Insulinemia, Testosterone

\section{Résumé}

Contexte: L'insuffisance en androgènes affecte les hommes à l'âge adulte, causant plusieurs effets nocifs aux niveaux reproductif et comportemental. Puisque l'aromatase est. une enzyme qui catalyse la conversion des androgènes en œstrogènes, et qu'elle est. responsable d'un équilibre adéquat des hormones sexuelles chez les hommes et les femmes, l'administration de molécules agissant comme freinateurs peut contribuer à restaurer une activité enzymatique anormale. Une étude prospective pilote a été menée pour étudier l'effet du D-chiro-inositol, un potentiel freinateur de l'aromatase, sur les taux sériques de testostérone, estradiol, estrone,

déhydroépiandrostérone et d'épiandrostérone d'un groupe d'hommes adultes volontaires. Le glucose, l'insuline, I'hormone folliculostimulante, I'hormone lutéinisante, l'inhibine B, le D-chiro-inositol et les taux sériques de myoinositol ont également été mesurés.

Résultats: Les hommes volontaires ont été sélectionnés selon l'âge et l'indice de masse corporelle. Les hommes qui présentaient une glycémie et/ou un statut hormonal altérés en raison d'un âge avancé ou d'un poids anormal, ont été inclus dans l'étude. Chacun des 10 volontaires enrôlés a pris du D-chiro-inositol (1 g/jour) par voie orale pendant un mois. Des dosages sériques des marqueurs sélectionnés ont été réalisés avant (témoin) et après le traitement. L'administration de D-chiro-inositol a été associée à une réduction des taux sériques de l'estrone (85.0\%) et de l'estradiol (-14,4\%), et a une augmentation des taux sériques de testostérone $(+23,4 \%)$ et de déhydroépiandrostérone (+ 13,8\%). En outre, les taux d'épiandrostérone étaient plus élevés (39\%) après le traitement. D'autre part, les taux d'hormone folliculostimulante, d'hormone lutéinisante et d'inhibine B n'ont pas été modifiés. Une tendance à la diminution de la glycémie, de l'insulinémie et de l'indice d'évaluation du modèle homéostatique a été observée après traitement par D-chiro-inositol, bien que les différences n'aient pas atteint une signification statistique. Le traitement par D-chiro-inositol n'a causé aucun effet indésirable notable.

Conclusions: L'augmentation des androgènes et la diminution des œestrogènes semblent confirmer que le D-chiroinositol agit comme un freinateur de l'aromatase, mais avec un mécanisme d'action encore inconnu. Cette étude pilote ouvre de nouvelles perspectives de recherche et d'applications thérapeutiques pour le D-chiro-inositol à différents dosages et durées de traitement.

Mots-clés: DHEAS, épiandrostérone, estradiol, estrone, glycémie, index HOMA, inhibine B, insulinémie, testostérone

\section{Introduction}

Testosterone (T) and Estradiol (E2) are essential in male physiology. Both hormones participate to the development of sexual characteristics during adolescence and contribute to general health in the adulthood [1-6]. The biosynthesis of $\mathrm{T}$ and its conversion to E2 involve enzymatic processes that maintain the delicate balance between the two hormones. Hence, an adequate regulation of the participating enzymes is of primary importance. In particular, the enzyme aromatase catalyzes the peripheral conversion of androgens to estrogens. Aromatase, also known as estrogen synthetase (gene CYP19A1), is widely expressed in several tissues and organs of the human body, including testis, granulosa of ovarian follicles, placenta, skin fibroblasts, prostate, adipose tissue, bones, breast, brain [7]. Furthermore, it was found also in vascular smooth muscle cells [8], skeletal muscles [9], liver [10] and gastric mucosa [11]. In particular, the adipose tissue that is very rich in aromatase content [12], produces considerable amount of circulating estrogens [13].

Alterations in the aromatase activity lead to an hormonal imbalance. In fact, excessive aromatase activity results in reduced levels of $\mathrm{T}$ and increased concentration of estrogens $[7,14]$. 
Men over 30 years old experience $1 \%$ annual reduction of serum $\mathrm{T}[15,16]$, with negative impact in their reproductive health. In addition, aromatase-dependent conversion of androstenedione (A4) into estrone (E1) increases with age and obesity [17].

Male androgen deficiency in the adulthood is highly prevalent, with rates increasing with age, from $4 \%$ (4049 years) to nearly $50 \%$ (over 80 years). Some studies suggest a $17 \%$ increase in deficiency of $\mathrm{T}$ for every decade of life [18-20]. Hormonal replacement therapy with $\mathrm{T}$ seems associated with possible severe side effects that include cardiovascular and thrombotic events, and polycythemia [21-30]. Therefore, the use of aromatase inhibitors (AIs) has attracted an increasing interest in the last decades [31, 32]. The latest generation of AIs, such as letrozole and anastrozole, inhibit the enzyme activity in a very specific fashion, but they also induce E2 depletion states that may expose patients to osteoporosis and cardiovascular risk [33], In this context, D-chiro-inositol (DCI) may constitute a safer alternative to AIs for increasing androgen levels. DCI is one of the nine inositol stereoisomers, a family of cyclic poly-alcohols that play several key functions in cell physiology [34]. While a small amount of DCI comes from dietary intake, endogenous production provides the majority of human body requirement. Indeed, an insulin-dependent epimerase synthesizes DCI from myo-inositol (Myo-Ins), which is the main component (over 99\%) of the cellular inositol pool. Such reaction occurs especially in the liver, muscles and blood, where the highest conversion rate $(\sim$ $60 \%$ ) is reported [35]. As inositol phosphoglycans (IPGs), both MI and DCI are insulin second messengers and influence cell metabolism, by activating key enzymes involved in oxidative and non-oxidative glucose metabolism [36]. Specifically, DCI participates in glycogen synthesis.

In the ovary, DCI modulates insulin-induced androgen biosynthesis [37] and increases $\mathrm{T}$ levels either directly, stimulating $\mathrm{T}$ biosynthesis in human ovarian thecal cells [38], and indirectly, decreasing the CYP19A1 aromatase gene expression in granulosa cells [39]. Based on these premises, researchers suggested that treatment with high doses of DCI may have clinical application in conditions where decreased estrogen levels is required [40, 41].

The aim of this pilot study was to test the effect of a 30-day DCI treatment on, upon T, E2, T/E2 ratio, Dehydroepiandrosterone sulfate (DHEAS), E1, Homeostatic Model Assessment (HOMA) index, glycemia, insulinemia, Follicle-stimulating hormone (FSH), Luteinizing hormone (LH), epiandrosterone (Epia) and inhibin B levels in male volunteers (V) selected by their age and body mass index (BMI). Serum concentrations of DCI and MI were also determined before and after DCI supplementation.

\section{Patients and methods Subject eligibility}

This prospective study was approved by the Local Ethics Committee of Alma Res Fertility Center in Rome, Italy (registration n. 005/2020), where the trial was carried out. Enrolment involved only male volunteers, evaluated on the basis of medical history, physical examination, and laboratory hormone screening (details below). All patients provided a written informed consent to participate in the study. Eligibility criteria were the following: (1) age range 30-65 years; (2) BMI between 22 and 34 $\mathrm{kg} / \mathrm{m}^{2}$; (3) moderate alteration of glycemia and/or testosterone and estradiol levels (within 15\% of the normal range). Individuals with a diagnosed or suspected disease, as well as those regularly taking psychoactive substances, dietary supplements or drugs that may interfere with the endpoints of this study were excluded. All participants were advised to follow their usual diet during DCI treatment.

To assess whether the sample was statistically adequate, a post hoc analysis was performed using the Wilcoxon signed-rank Test for matched pairs, with alpha $=$ 0.05 .

\section{Study design and intervention}

All volunteers were instructed to take oral DCI $(1.0 \mathrm{~g}$ in total) two times a day, morning and evening, on an empty stomach to maximize intestinal absorption. Treatment duration was 30 days. DCI was provided by Amicogen, Gyeongsangnam-do, South Korea in $500 \mathrm{mg}$ capsules (purity of 96.53\%) specifically manufactured for this study. Baseline (t0) values were obtained from the volunteers and used as reference.

Given that current information prevents to set exact boundaries to DCI therapeutic profile, dosage and treatment length for this study were determined based on the available evidence on DCI efficacy and safety in males and females [42-48]. Because increased testosterone level is expected after DCI treatment, clinical studies on testosterone administration were also taken into consideration. Indeed, excess $\mathrm{T}$ may induce testicular atrophy and sterility due to decreased systemic FSH and LH levels [49]. As DCI leads to a down-regulation of the aromatase enzyme [39], a long-term administration may cause potentially harmful testosterone levels. Considering that all volunteers were basically healthy individuals, a 30-day treatment was deemed adequate to observe hormonal changes without causing imbalance of sex hormones.

The primary outcome of this study was the increase of T/E2 ratio, a reliable index of aromatase activity [50]. Secondary outcomes were changes of T, DHEAS, E1, E2, HOMA index, glycemia, insulinemia, FSH, LH, inhibin $B$ and epiandrosterone. In addition, serum concentrations 
of DCI and MI were assessed before and after 30 days of supplementation with DCI.

\section{Sample collection and preparation}

Blood samples were collected by venipuncture at the baseline and after 30 days of DCI treatment. Blood samples were centrifuged, and serum was stored at $-20^{\circ} \mathrm{C}$ until assayed.

\section{Serum assays}

Serum levels of T, DHEAS, E1, E2, FSH, LH, glycemia, insulinemia, inhibin B and Epia were measured by Raphael Medical Lab, using commercial kits (T: Chemiluminescent Immunoassay System, Beckman Coulter, Brea, CA, USA; DHEAS: Chemiluminescent Immunoassay System, Siemens, Munich, Germany; E1: ELISA kit, Dasit, Milan, Italy; E2: Chemiluminescent Immunoassay System, Beckman Coulter, Brea, CA, USA; Epia: Enzyme Immunoassay Kit, Arbor Assays, Ann Arbor, Michigan, USA; FSH: Chemiluminescent Immunoassay System, Beckman Coulter, Brea, CA, USA; inhibin B: ELISA kit, Skylab, Ansh Labs, Webster, Texas, USA; LH: Chemiluminescent Immunoassay System, Beckman Coulter, Brea, CA, USA; glycemia: Trinder glucose oxidase method, Werfen Company, Milan, Italy; Insulinemia: Chemiluminescent Immunoassay System, Beckman Coulter, Brea, CA, USA). The following standard ranges were used as reference for the analyses: T: $1.75-7.81 \mathrm{ng} / \mathrm{ml}$; E2: $20-47 \mathrm{pg} / \mathrm{ml}$; E1: 9.0$79.1 \mathrm{pg} / \mathrm{ml}$; DHEAS: $80-560 \mu / \mathrm{dl}$; glycemia $70-105 \mathrm{mg} /$ $\mathrm{dL}$; insulinemia 1.9-23.0 $\mu \mathrm{UI} / \mathrm{ml}$; FSH: $1.27-19.26 \mathrm{mUI} /$ $\mathrm{ml}$; LH: $1.24-8.62 \mathrm{mUI} / \mathrm{ml}$; inhibin B: $24-310 \mathrm{pg} / \mathrm{ml}$. Quantification of serum levels of DCI and MI $(\mu \mathrm{mol} / \mathrm{l})$ was performed by Mérieux NutriSciences Italia (ResanaTreviso, Italy), and carried out according to the following procedure. After extraction with organic solvents and derivatization, samples were analyzed by gas chromatography - mass spectrometry with GC/MS Agilent 6890 (Agilent, Santa Clara, CA, USA). The injection (1.0 $\mu \mathrm{l})$ was performed in a splitless mode at $270{ }^{\circ} \mathrm{C}$, using a capillary column Agilent $122-5532 \mathrm{~dB}-5 \mathrm{~ms} \quad(0.25 \mathrm{~mm} \times 30 \mathrm{~m} \times$ $0.25 \mu \mathrm{m})$. The total run-time lasted $15 \mathrm{~min}$ : oven at $70^{\circ} \mathrm{C}$ from 0 to $1 \mathrm{~min} ; 20^{\circ} \mathrm{C} / \mathrm{min}$ to $150{ }^{\circ} \mathrm{C} ; 10^{\circ} \mathrm{C} / \mathrm{min}$ to $240{ }^{\circ} \mathrm{C} ; 4 \mathrm{~min}$ at $320^{\circ} \mathrm{C}$ post-run. The flow rate was kept at $1.2 \mathrm{ml} / \mathrm{min}$, and analytes were detected with a 5973 Network Series Mass Selective detector in selected ion monitoring (SIM) modality. Cmax (maximum concentration recorded) and Tmax (time to reach Cmax) were calculated from the chromatograms.

\section{Statistical analysis}

Descriptive statistics summarizing quantitative variables included median values, as well as the 25 th and the 75 th percentiles. Wilcoxon signed rank sum test was performed to compare changes from t0 (baseline) to t1 (after DCI treatment) for all parameters evaluated in the study. Data are presented using box plots. Statistical analysis was implemented as two-sided testing with 0.05 significance level, using $\mathrm{SAS}^{\oplus}$ version 9.4 (SAS Institute Inc. 100 SAS Campus Drive Cary, NC, USA) and Stata ${ }^{\mathrm{TM}}$ version 8.2 (StataCorp LLC, College Station, TX, USA).

\section{Results}

Among 42 screened volunteers, ten (V1-V10) satisfied the criteria and entered the study. The post hoc analysis demonstrated that the sample size was statistically adequate, with power of the study greater than $90 \%$.

It is important to point out that none of the study participants reported any type of adverse events.

The age range of the selected volunteers was 30-55 years, with a median value of 37.0 years (25th and 75 th percentiles: 34.3 and 42.3 , respectively). The BMI median value was 27.5 (26.1 and 29.6). Two subjects had normal weight (BMI: 23.4 and 22.9), 6 were overweight (BMI between 25.8 and 29.7), and 2 were obese (BMI: 30.9 and 33.6). These values were found unchanged after treatment with DCI.

Median, as well as the 25th and the 75th percentile values were determined for T, E2, E1, DHEAS, FSH, LH, inhibin $\mathrm{B}$, glycemia, insulin and HOMA index at the baseline (t0) and after DCI treatment (t1). Table 1 reports the baseline values of glycemia, insulinemia, HOMA index, DCI, MI and BMI for each volunteer.

All men had normal baseline levels of $\mathrm{T}$ (median: 4.4; 25th and the 75th percentile values: 3.9 and 4.6, respectively), E2 (median: 27.4 percentiles: 25.3 and 30.3), T/E2 (median: 16.8; percentiles: 13.3 and 19.0), FSH (median: 8.2; percentiles: 4.8 and 10.7), LH (median: 3.8 ; percentiles: 3.2 and 4.4) and inhibin B (median: 110.4; percentiles: 97.7 and 126.7). Conversely, six volunteers exhibited higher E1 levels than normal (109.4, 121.6, 103.0, 166.6, 105.2, 260.0 pg/ml); E1 median value at baseline was $104.1 \mathrm{pg} / \mathrm{ml}$ (percentiles: 63.9 and 118.6). These anomalies were unrelated to age or BMI (data not shown). Three subjects had baseline DHEAS levels lower than normal $(66.5,22.0,54.0 \mu \mathrm{g} / \mathrm{dl})$, but they increased after DCI treatment; the other volunteers had baseline DHEAS levels within the physiological range (80$560 \mu \mathrm{g} / \mathrm{dl}) ;$ DHEAS median value at baseline was $210.0 \mu \mathrm{g} / \mathrm{dl}$ (percentiles: 73.9 and 282.8).

One obese (V9) and three overweight subjects (V1, V3, and V4) had moderately higher glycemia than normal. In contrast, one obese (V10) and three overweight volunteers (V2, V6, and V8) were normoglycemic.

Overall, the evaluated sample group displayed the variability found in a western population, with a prevalence of overweight subjects. 
Table 1 Glycemia, insulinemia, Homeostatic Model Assessment (HOMA) index, D-chiro-inositol (DCl), myo-inositol (MI) and Body Mass Index (BMI) values at baseline in volunteers V1-V10

\begin{tabular}{|c|c|c|c|c|c|c|}
\hline Volunteers & glycemia mg/dl & insulinemia $\mu \mathrm{IU} / \mathrm{ml}$ & HOMA index $\left({ }^{\mathrm{a}}\right)$ & $\mathrm{DCl} \mu \mathrm{mol} / \mathrm{l}$ & $\mathrm{MI} \mu \mathrm{mol} / \mathrm{l}$ & BMI \\
\hline$\overline{\mathrm{V} 1}$ & 117 & 32.16 & 9.3 & 0.15 & 13.0 & 29.7 \\
\hline V2 & 101 & 4.58 & 1.15 & 0.16 & 13.5 & 27.3 \\
\hline V3 & 109 & 5.60 & 1.5 & 0.16 & 14.3 & 29.4 \\
\hline V4 & 110 & 4.18 & 1.14 & 0.25 & 15.0 & 27.0 \\
\hline V5 & 88 & 6.91 & 1.5 & 0.29 & 16.4 & 23.4 \\
\hline V6 & 86 & 9.66 & 2.06 & 0.49 & 18.0 & 27.6 \\
\hline V7 & 95 & 8.93 & 2.09 & 0.70 & 18.0 & 22.9 \\
\hline V8 & 93 & 8.70 & 2 & 0.71 & 20.8 & 25.8 \\
\hline V9 & 110 & 7.19 & 1.96 & 0.90 & 20.8 & 33.6 \\
\hline V10 & 90 & 5.82 & 1.29 & 0.90 & 21.0 & 30.9 \\
\hline \multicolumn{7}{|l|}{ Percentiles } \\
\hline 25 & 90.8 & 5.7 & 1.3 & 0.18 & 14.5 & 26.1 \\
\hline 50 & 98.0 & 7.1 & 1.5 & 0.39 & 17.2 & 27.5 \\
\hline 75 & 109.8 & 8.9 & 2.1 & 0.71 & 20.8 & 29.6 \\
\hline
\end{tabular}

Individual results and Percentiles (25th, 50th and 75th) of Glycemia, Insulinemia, BMI Body Mass Index, HOMA Homeostatic Model Assessment, DCI D-chiro-inositol and $\mathrm{MI}$ myo-inositol in the Study cohort of 10 volunteers (V1-V10)

$\left({ }^{\mathrm{a}}\right)$ arbitrary units

DCI administration for 30 days improved all sex hormone values analyzed in this pilot study. In particular, DCI treatment resulted in a $23.4 \%$ increase of $\mathrm{T}(p=$ 0.0020) (Fig. 1a). This remarkable effect was observed in nine out of 10 volunteers, even if baseline $\mathrm{T}$ levels were already withing the normal range (Fig. 1b).

Moreover, DCI treatment induced an overall $14.4 \%$ decrease of E2 values. Although such decrease was observed in 9 out of 10 individuals, the differences failed to reach statistical significancy $(p=0.0645)$ (Fig. 2a). Only one volunteer experienced increased E2 levels at $\mathrm{t} 1$ (V4, $\mathrm{t} 0=41.4 \mathrm{pg} / \mathrm{ml} ; \mathrm{t} 1=46.4$ ). (Fig. 2b).

Based on these results, DCI treatment significantly increased the overall T/E2 ratio by $36 \%(p=0.0020)$ (Fig. 3a). The individual results of T/E2 ratios for each patient revealed a consistent increase, with a pattern very similar to $\mathrm{T}$ (median values of $\mathrm{T} / \mathrm{E} 2$ ratio, $\mathrm{t} 0=$ $10.9 \%, \mathrm{t} 1=12.3 \%)$ (Fig. $3 \mathrm{~b}$ ):

In addition to these findings, DCI treatment resulted in an overall $85 \%$ decrease of E1 values when compared to those at baseline (Fig. 4a). All the subjects with baseline E1 levels above the physiological range exhibited normal values after DCI treatment (Fig. 4b). Indeed, E1 decreases in all subject except one (V6), who maintained almost unaffected E1 levels. However, DCI effect on the increase of $\mathrm{T}$ levels in this case was remarkable (+ $33.9 \%)$.

Moreover, the overall DHEAS concentration increased by $13.8 \%$ after $\mathrm{DC} 1$ treatment $(\mathrm{t} 0=210 \mu \mathrm{g} / \mathrm{dl}, \mathrm{t} 1=$ $239 \mu \mathrm{g} / \mathrm{dl} ; p=0.049)$. Both $\mathrm{T}$ and DHEAS remained within the normal range after the treatment (Fig. 5).
Glycemia, insulinemia and HOMA index were also evaluated before and after DCI treatment. While no significant differences were found between t 0 and $t 1$, a trend towards a decrease was observed for all three outcomes (Figs. 6 and 7). DCI treatment restored glycemia to normal values in 3 out of 4 males with abnormal baseline levels (the individual values decreased from 117, 109 and 110 to 101, 101 and 92, respectively). No significant changes were found for $\mathrm{LH}$ and FSH serum levels after DCI treatment, compared to the baseline. (Fig. 8).

Inhibin B levels were also determined in all 10 volunteers, finding no changes when comparing results before and after DCI administration. The median value was $110.4 \mathrm{pg} / \mathrm{ml}$ (percentiles: 97.7 and 126.7) at baseline, and $110.7 \mathrm{pg} / \mathrm{ml}$ (percentiles: 99.0 and 126.2) at t1.

After obtaining the data described above, Epia serum levels were also assessed. As a sufficient sample amount was not available from all samples to run individually, a preliminary evaluation was carried out on pooled sera from all ten volunteers. The results revealed a 39\% increase in Epia concentration, with a baseline value of $44.62 \mathrm{ng} / \mathrm{ml}$ and a t1 value of $62.14 \mathrm{ng} / \mathrm{ml}$.

\section{Pharmacokinetics of $\mathrm{DCl}$ single dose}

To evaluate the pharmacokinetic profile of DCI in the study participants, all volunteers ingested a single dose $(1 \mathrm{~g})$ of DCI ten days before starting the treatment for the study. The results are shown in Fig. 9. After a single DCI administration, serum levels peaked at $240 \mathrm{~min}$, remaining almost constant for one additional hour. The values of the main parameters were: Cmax: $9.40 \mu \mathrm{mol} / \mathrm{l}$; 
A.

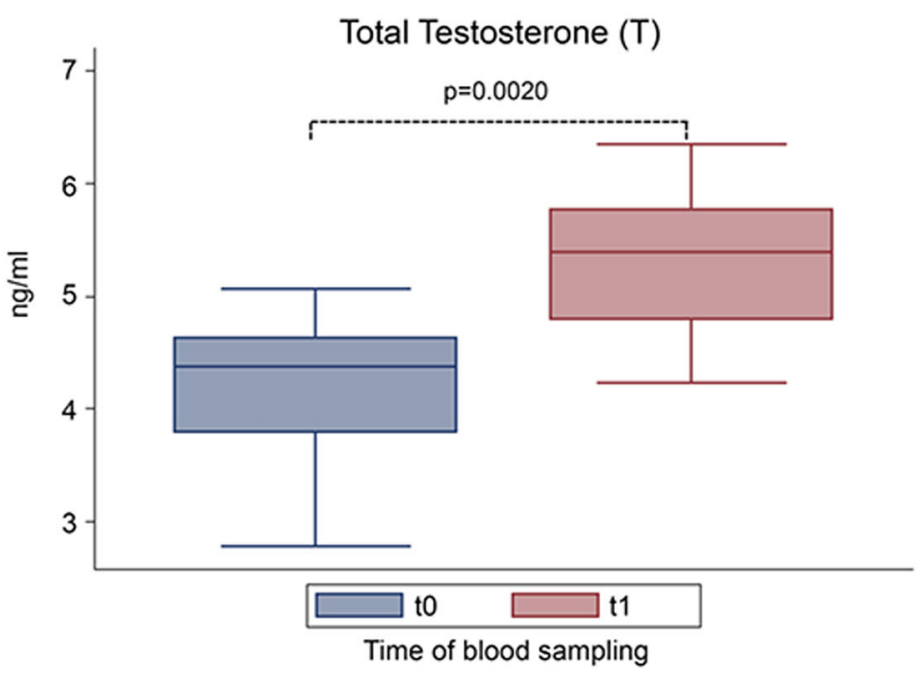

B.

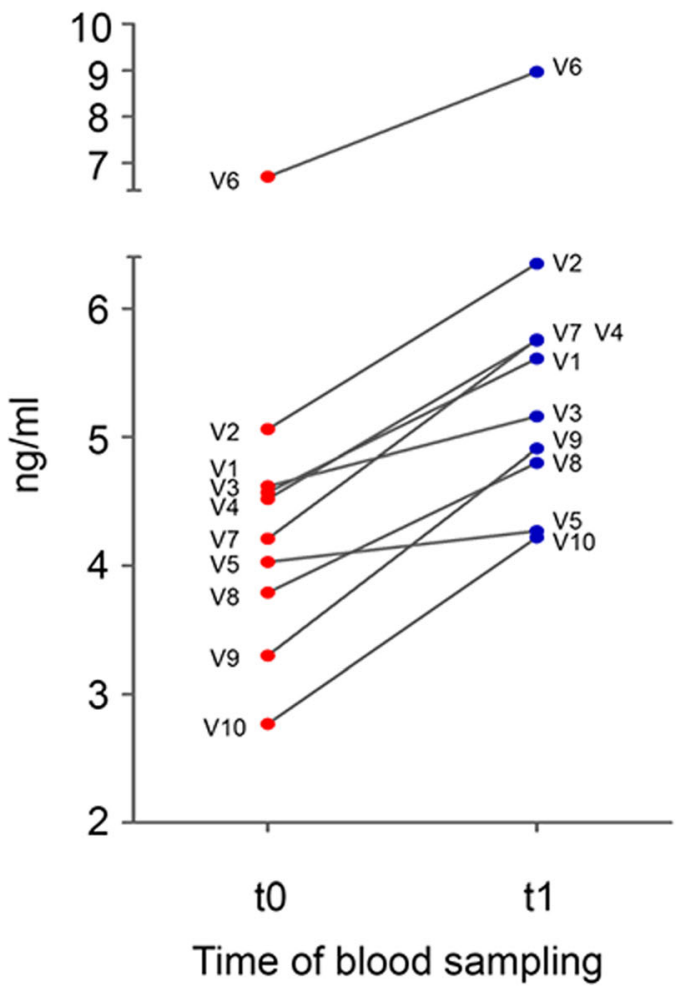

Fig. 1 Effect of D-chiro-inositol (DCI) treatment on total testosterone ( $\mathrm{T}$ ) levels. Total serum T levels from 10 male volunteers at baseline (t0) and after 30 days of treatment (t1) with $1 \mathrm{~g} \mathrm{DCl}$ per day are presented as: a median values of total $\mathrm{T}$ (box plots). The boxes denote the interquartile range between the first and third quartiles (25th and 75th percentiles, respectively), the whiskers represent the minimum and maximum values, and the line inside the boxes represents the median value ( $p=0.0020$; Wilcoxon signed rank sum test); $\mathbf{b}$ individual total T values (before-after treatment). The graph reports the values for each volunteer participating in the study 
A.

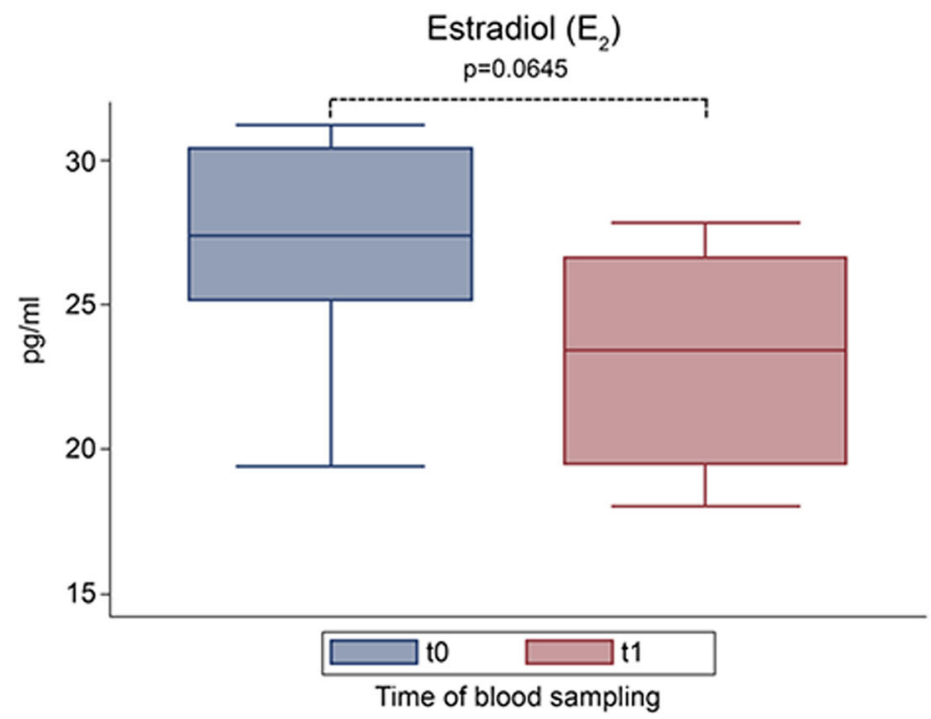

B.

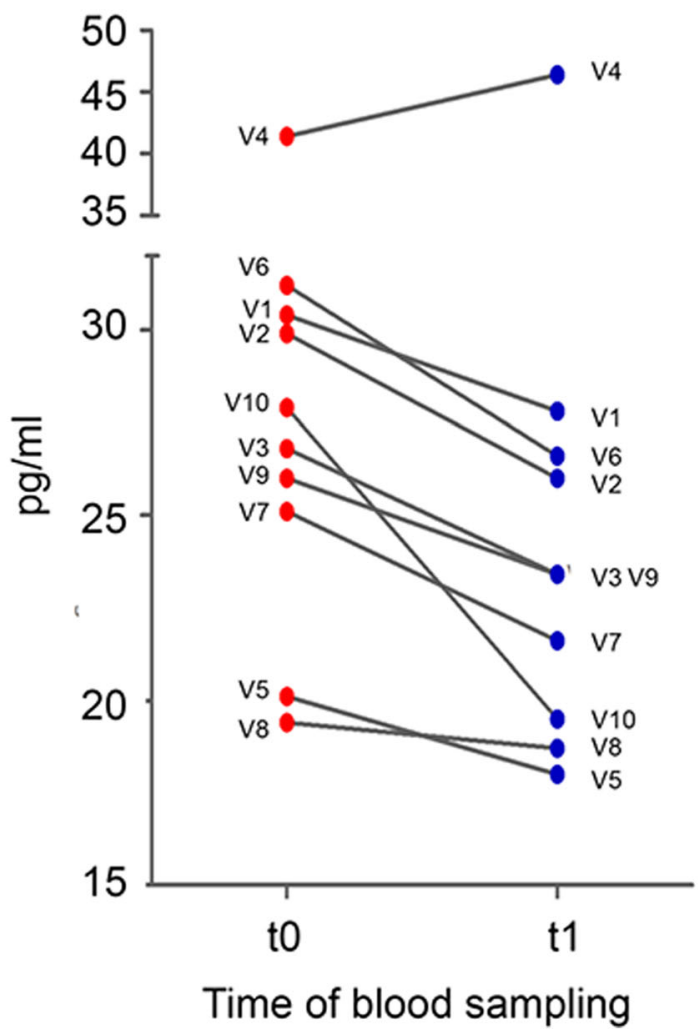

Fig. 2 Effect of D-chiro-inositol (DCl) treatment on Estradiol (E2) levels. E2 levels from 10 male volunteers at baseline (t0) and after 30 days of treatment (t1) with $1 \mathrm{~g} \mathrm{DCl}$ per day are presented as: a median values of E2 (box plots). ( $p=0.0645$; Wilcoxon signed rank sum test). Symbol explanation: see caption of Fig. 1a; b individual E2 values (before-after treatment). The graph reports the values for each volunteer participating in the study 
A.

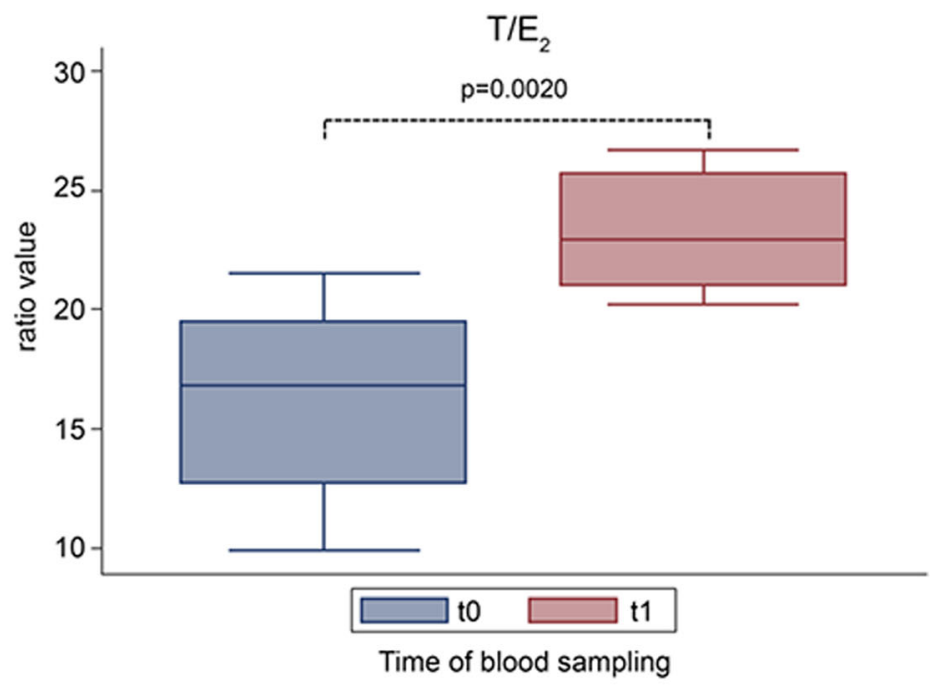

B.

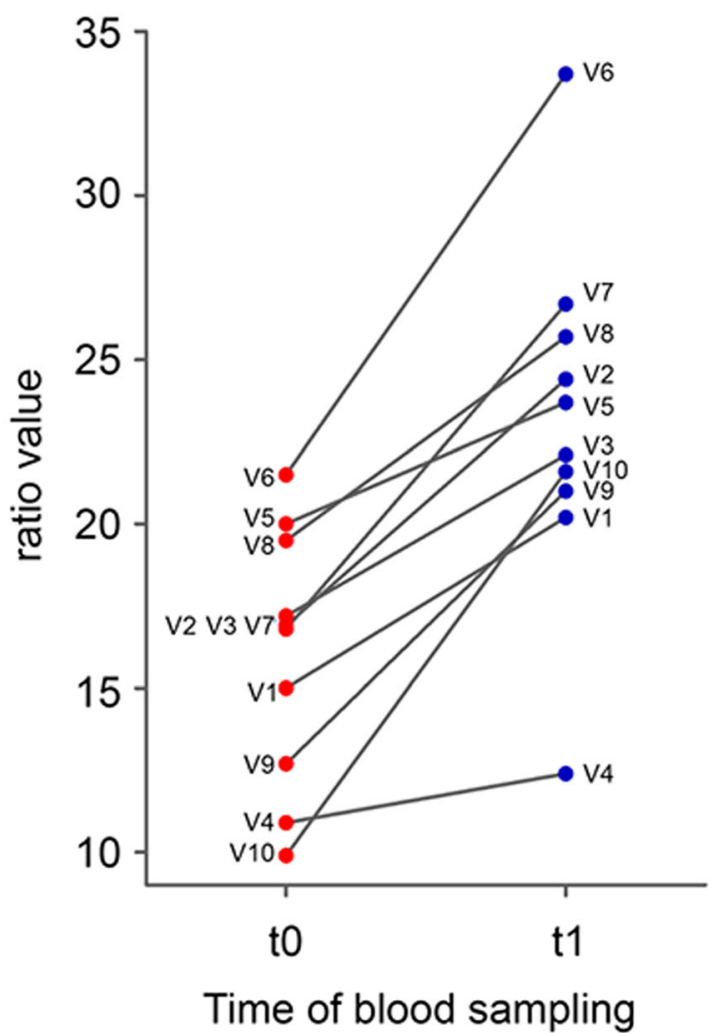

Fig. 3 Effect of D-chiro-inositol (DCl) treatment on testosterone/estradiol (T/E2) ratio. T/E2 ratio from 10 male volunteers at baseline (t0) and after 30 days of treatment ( $\mathrm{t} 1)$ with $1 \mathrm{~g} \mathrm{DCl}$ per day are presented as: a median values of T/E2 ratio (box plots) $(p=0.0020$; Wilcoxon signed rank sum test). Symbol explanation: see caption of Fig. 1a; $\mathbf{b}$ individual T/E2 ratio (before-after treatment). The graph reports the values for each volunteer participating in the study 
A.

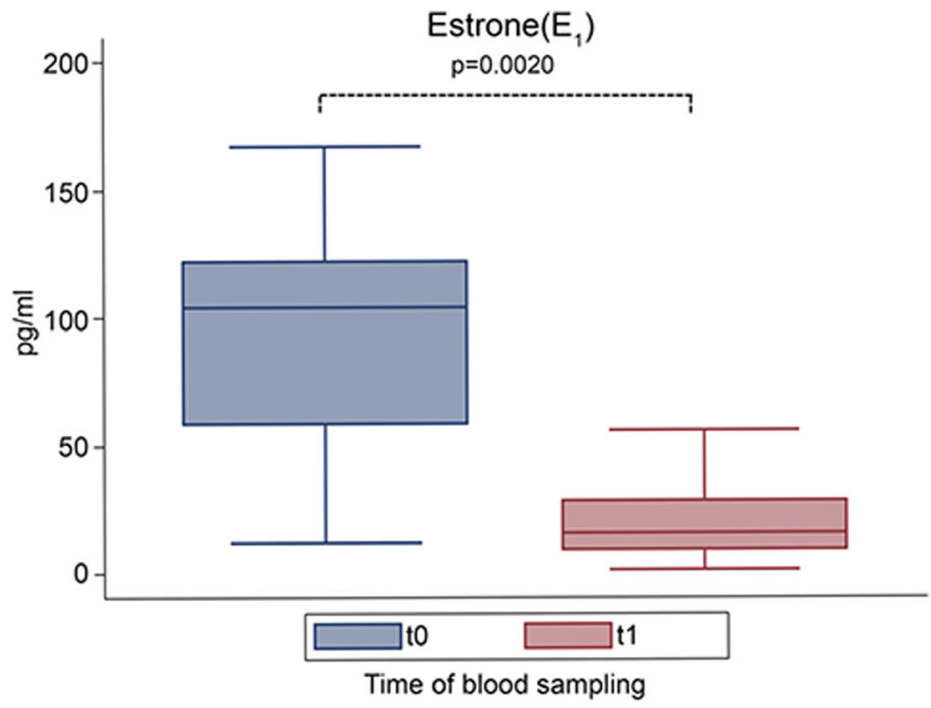

B.

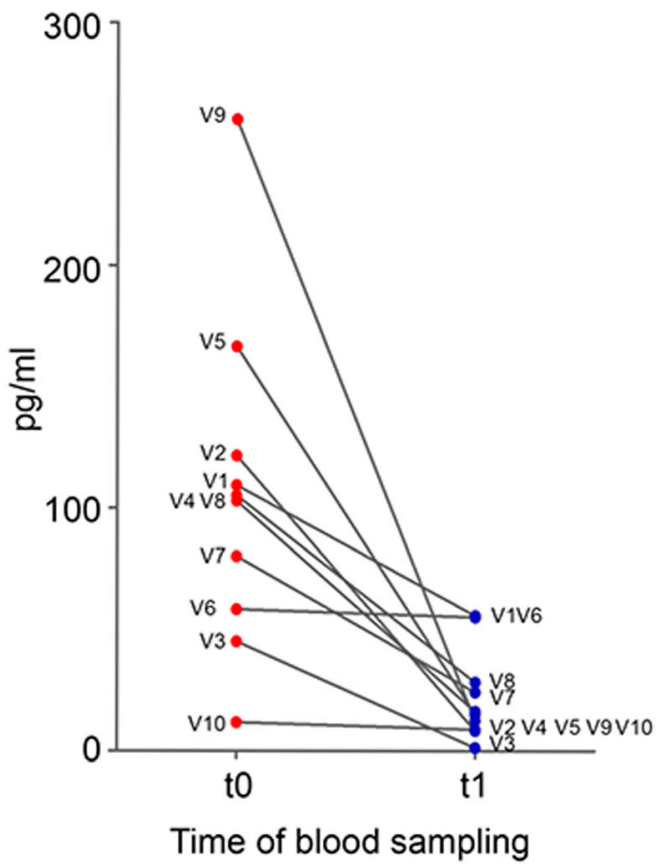

Fig. 4 Effect of D-chiro-inositol (DCl) treatment on estrone (E1) levels. E1 levels from 10 male volunteers at baseline (t0) and after 30 days of treatment (t1) with $1 \mathrm{~g} \mathrm{DCl}$ per day are presented as: a median values of $\mathrm{E} 1$ (box plots) ( $p=0.0020$; Wilcoxon signed rank sum test). Symbol explanation: see caption of Fig. 1a; $\mathbf{b}$ individual E1 levels (before-after treatment). The graph reports the values for each volunteer participating in the study

Tmax: 240 min; AUC (0-420): 2750.59. The average serum concentration increased forty-seven-fold with respect to baseline values (median value: $0.2 \mu \mathrm{mol} / \mathrm{l}$ ). These results were also compared with previous similar studies carried out with MI. Of note, the shape of the DCI curve is shifted to the right in comparison with MI, which showed a peak at $180 \mathrm{~min}$ [51]. This result led us to suggest that DCI has a longer serum half-life than MI. At $420 \mathrm{~min}$, DCI levels significantly decreased when compared to those determined at $300 \mathrm{~min}(p=0.0020)$.

$\mathrm{DCl}$ and $\mathrm{MI}$ serum levels before and after $\mathrm{DCl}$ treatment $\mathrm{DCI}$ and MI serum concentrations were within the normal range in all volunteers before starting the study 


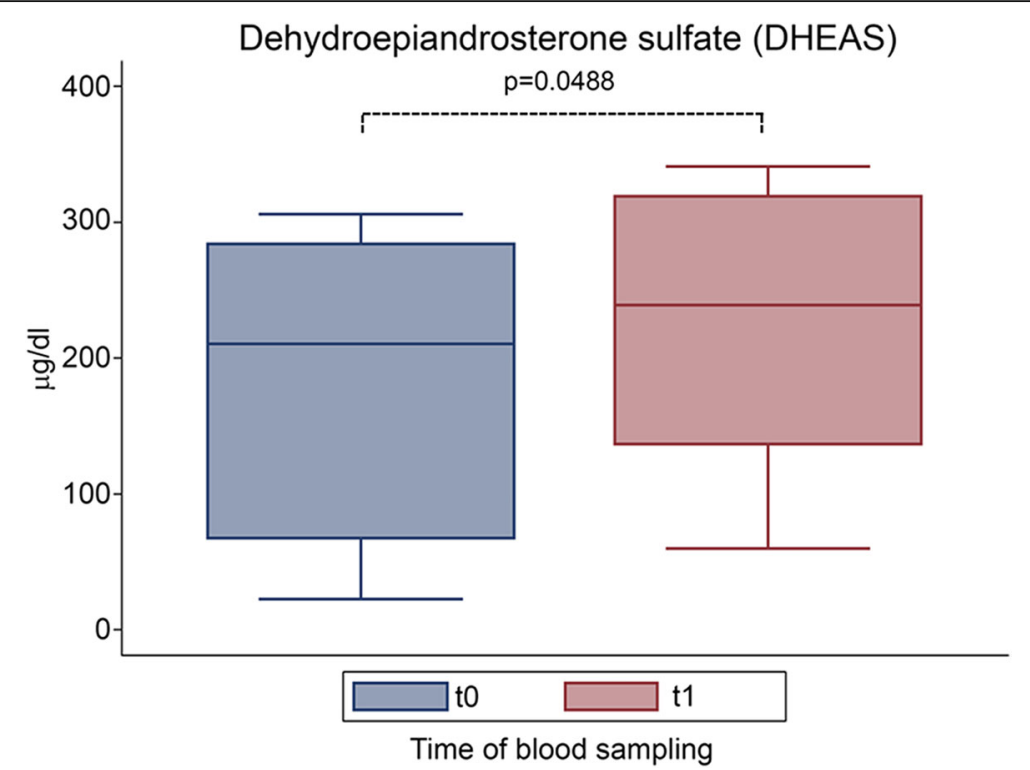

Fig. 5 Effect of D-chiro-inositol (DCl) treatment on dehydroepiandrosterone sulfate (DHEAS) levels. DHEAS levels from 10 male volunteers at baseline ( $\mathrm{t} 0$ ) and after 30 days of treatment ( $\mathrm{t} 1)$ with $1 \mathrm{~g} \mathrm{DCl}$ per day are presented as median values of DHEAS (box plots) ( $p=0.0488$; Wilcoxon signed rank sum test). Symbol explanation: see caption of Fig. 1a

treatment $(0.18-0.40 \mu \mathrm{mol} / \mathrm{l}$ for DCI, and $15-30 \mu \mathrm{mol} / \mathrm{l}$ for MI). Accordingly, the MI/DCI ratio was very close to physiological values (40:1 in serum). After the treatment, DCI levels increased about 40-fold $(p=0.0001)$, while the MI concentration had a much smaller change $(+$ $30 \%)$, as reported in Table 2.

\section{Discussion}

This pilot study was carried out in male volunteers, mainly constituted by overweight individuals. Patient treatment with DCI reduced serum concentrations of estrogens E2 and E1, with a stronger effect on the latter. Moreover, DCI administration resulted in increased levels of androgens $\mathrm{T}$ and DHEAS, both remaining within the normal range. Based on these findings, an improvement in T/E2 ratio was achieved at the end of the treatment. DCI restored normal values of glycemia in almost all subjects with levels above the physiological range, however such changes did not reach statistical significancy. Longer periods of administration may be required to observe anti-glycemic effects in all patients. FSH, LH and inhibin B levels of all 10 volunteers, all within the normal range at $\mathrm{t} 0$, were found unchanged after DCI treatment.

Taking into account the values of glycemia for each participant and the lack of significancy for variations related to the treatment, DCI-induced changes of sex hormone balance seem unrelated to any previous modification of glycemia.

In the present study, no significant changes were found in inhibin B serum levels after DCI treatment.
Previously, Calogero et al. [52] reported an increase in inhibin B levels following MI treatment (4 $\mathrm{g}$ per day for 3 months) in men with idiopathic infertility. The patients included were below 45 years, with age and BMI average values of $28 \pm 9$ years and $26.6 \pm 2.7$, respectively. The authors found a significant decrease of LH and FSH, and an increase of inhibin. Beside the use of different inositol isomers, other distinctions between such study and ours must be pointed out. In the study of Calogero et al., MI dosage was four-fold higher than DCI in our study, and the treatment period was three times longer. Furthermore, the characteristics of the study population are quite different between the two studies (age, BMI, etc.). Calogero et al. [52] found an average baseline inhibin B value of $86 \pm 24 \mathrm{pg} / \mathrm{ml}$. Although within the normal range $(24-310 \mathrm{pg} / \mathrm{ml}$ in the overall population) [53], the reported values were lower than those found in our population $(110.4 \mathrm{pg} / \mathrm{ml}$ at $\mathrm{t} 0$ and $110,7 \mathrm{pg} / \mathrm{ml}$ at $\mathrm{t} 1)$.

We think that DCI exerts very specific effects and the evidence available so far does not allow to employ it in the therapy for male infertility, where MI is the only inositol isomer to be used for the treatment.

Other two studies from the same research group report the impact of DCI in male reproduction and health. The first one evaluated the effects of DCI on spermatozoa in vitro [54], using semen samples from 15 asthenozoospermic patients and 15 normozoospermic healthy males. Samples were incubated with different DCI concentrations $(0,75$, and $750 \mu \mathrm{g} / \mathrm{mL})$ for $30 \mathrm{~min}$, resulting in increased sperm mitochondrial membrane potential (MMP), thus demonstrating for the first time a positive 


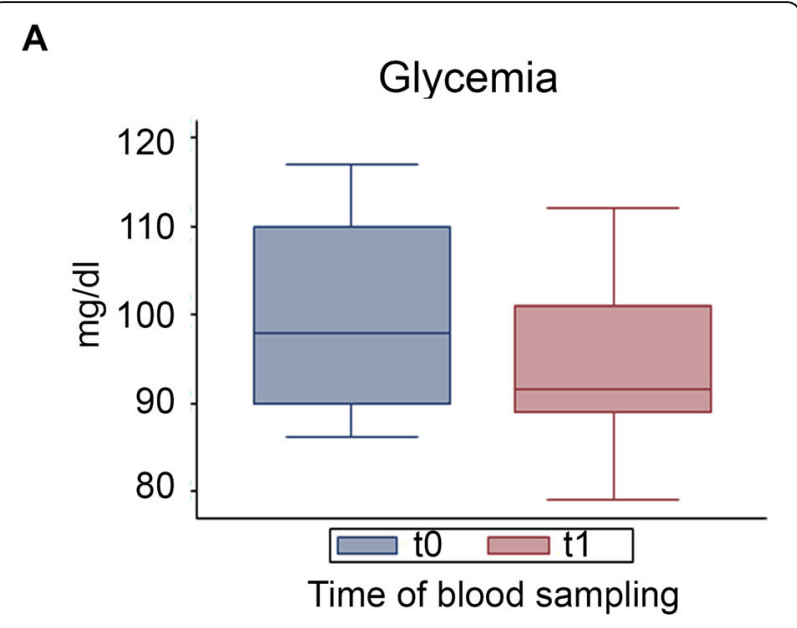

B

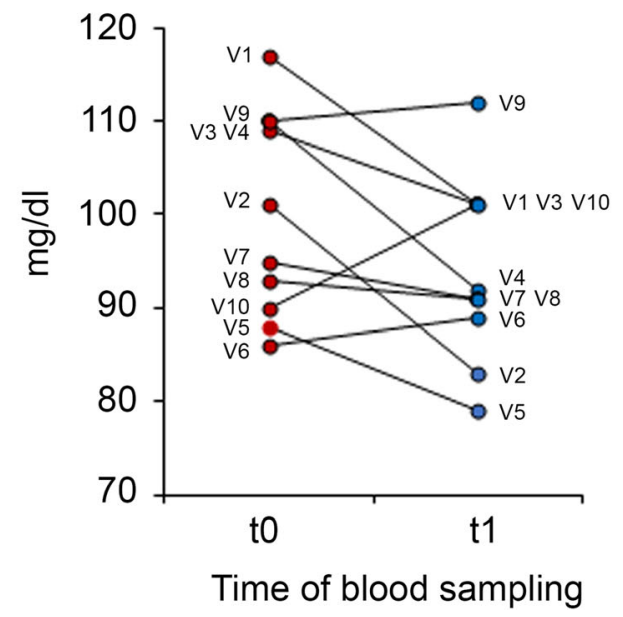

Fig. 6 Effect of D-chiro-inositol (DCl) treatment on glycemia levels. Glycemia levels from 10 male volunteers at baseline (t0) and after 30 days of treatment ( $\mathrm{t} 1)$ with $1 \mathrm{~g} \mathrm{DCl}$ per day are presented as: a median values of glycemia (box plots) ( $p=0.1113$; Wilcoxon signed rank sum test). Symbol explanation: see caption of Fig. 1a; $\mathbf{b}$ individual glycemia levels (before-after treatment). The graph reports the values for each volunteer participating in the study

in vitro effect of DCI on sperm function of asthenozoospermic patients. However, previous similar experiments with MI gave better results, as MI improved the abnormal sperm parameters in males with oligo-asthenoteratozoospermia (OAT), besides those in asthenozoospermic subjects. Of note, MI exerted its effects in the same incubation time used for DCI $(30 \mathrm{~min}$.) [55]. Furthermore, Condorelli et al. did not evaluate progressive motility, whereas it was significantly improved by in vitro MI treatment [55].

The second study [56] assessed the effect of estrogen modulation on prostatic health, as hyperestrogenism is associated with prostate inflammation. These data are convincing and open therapeutic perspectives for the use of DCI, that could help maintain prostate health. However, in our opinion, the best target in males for DCI administration is "mild hypogonadism".

As mentioned, DCI treatment in healthy volunteers resulted in higher levels of DHEAS, from which Epia derives. However, DHEAS increased by $13.8 \%$, whereas Epia by $39 \%$. Further studies are necessary to confirm these differences and their significance. Although our data refer only to male patients, it is interesting to highlight that high levels of Epia are associated with a substantial risk of developing PCOS in females [57]. Such increase can be considered a risk indicator, should the same trend be confirmed in women treated with DCI. In-depth specific studies should be carried out in the future to better understand this intriguingly complex set of events.

Based on the observed increased androgens and decreased estrogens, we are starting to consider DCI as an aromatase modulator, although the precise mechanism (direct or indirect) of action remains to be elucidated. The aromatase modulation is a dose-dependent phenomenon, and different tissues and organs respond in a different manner. This may also explain the partial efficacy of aromatase inhibitors in men [31]. An incomplete suppression may be regarded as advantageous because it prevents excessive reduction of estrogen levels in men and the possible associated adverse effects [31]. This is a research area that may be addressed in future studies to investigate in depth the activity of DCI as an aromatase down-regulator.

In our study, DCI treatment modified E1 serum levels in a remarkable way. At baseline, its median value was above the range, as 6 volunteers had abnormal levels. This value became normal after DCI treatment, and in all six men E1 levels were restored to normal. A study published in 2013 demonstrated that E1 is a reliable predictive marker of Type 2 Diabetes Mellitus (T2DM) [58]. In the report of a community-dwelling men, the authors found that E1 levels were prospectively associated with incidental T2DM. Conversely, analogous association was not found with E2. The significant association between E1 and the risk of T2DM could be explained by the differential actions of E1 on estrogen receptor subtype alpha $(E r \alpha)$ and estrogen receptor subtype beta $(\operatorname{Er} \beta)$ $[59,60]$. E1 and E2 bind to both Ero and $\operatorname{Er} \beta$, with E2 exhibiting greater affinity and activity than E1 in several in vitro tests. The associated specificity can lead to different pharmacological effects of estrogen receptor modulators. For example, randomized trials revealed an increased risk of T2DM in women treated with tamoxifen, compared to those from a placebo group. Instead, raloxifen treatment was not associated with analogous risk [61]. Accordingly, the correlation of E1, but not E2, with T2DM risk may be ascribable to their differential 

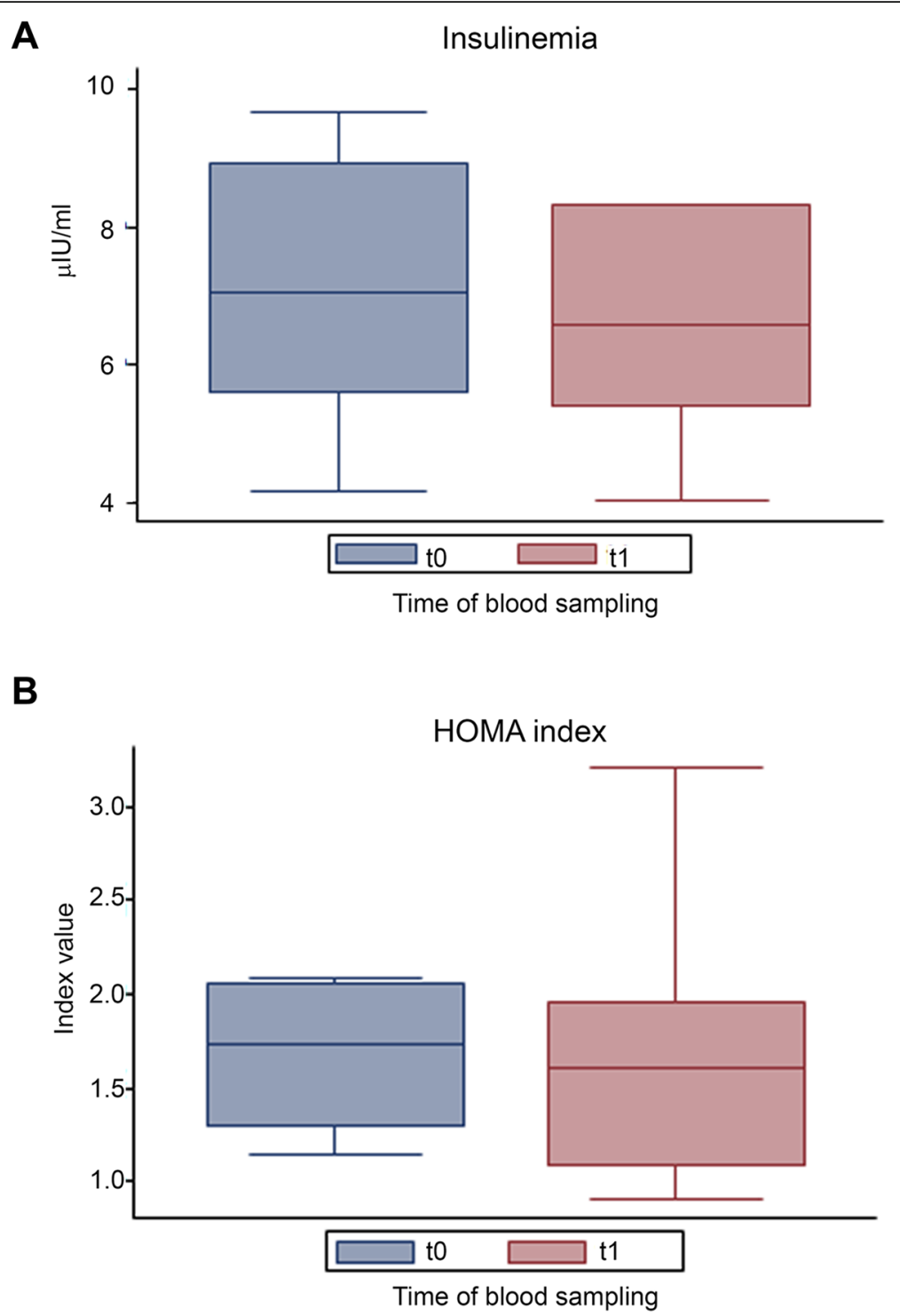

Fig. 7 Effect of D-chiro-inositol (DCl) treatment on insulinemia and HOMA index levels. Insulinemia and HOMA index from 10 male volunteers at baseline ( $\mathrm{t} 0$ ) and after 30 days of treatment ( $\mathrm{t} 1$ ) with $1 \mathrm{~g} \mathrm{DCl}$ per day are presented as median values of (a) insulinemia and (b) HOMA index (box plots) (insulinemia, $p=0.3750$; HOMA index, $p=0.3594$; Wilcoxon signed rank sum test). Symbol explanation: see caption of Fig. 1a

activity on estrogen receptor subtypes [58]. The biologic function played by E1 in men is often under-considered. Although E1 binds to receptors with lower affinity than E2 in some bioassays, circulating E1 levels in men are often appreciable [58]. Moreover, E1 can be converted to E2 in the organism. Furthermore, whether E1 exerts additional non-genomic effects on insulin secretion or sensitivity is still unknown, therefore the signal pathways involved in the E1 role on the T2DM risk should be explored. In the present study, we found that DCI reduces E1 levels, suggesting that DCI counteracts the onset of T2DM not only through its direct hypoglycemic activity related to its involvement in insulin signalling pathway $[62,63]$. DCI activates glycogen synthase and stimulates pyruvate dehydrogenase phosphatase, supporting ATP synthesis and favouring overall glucose cellular management [62]. Based on this profile, DCI alone was suggested for treating hyper-insulinemic illnesses such as metabolic syndrome, T2DM and Polycystic Ovary Syndrome (PCOS) [42-48], although some notable concerns have arisen in recent years about its use in PCOS [64-66].

DCI activity as hypoglycemic agent was recently confirmed by a preclinical study [67] that highlighted a new mechanism of action of DCI to decrease gluconeogenesis in insulin-resistant hepatocytes. This effect occurs via PI3K/AKT/FOXO1-mediated inhibition of glucose-6phosphatase and cytosolic phosphoenolpyruvate carboxykinase mRNA expression [67]. In the study, DCI was 

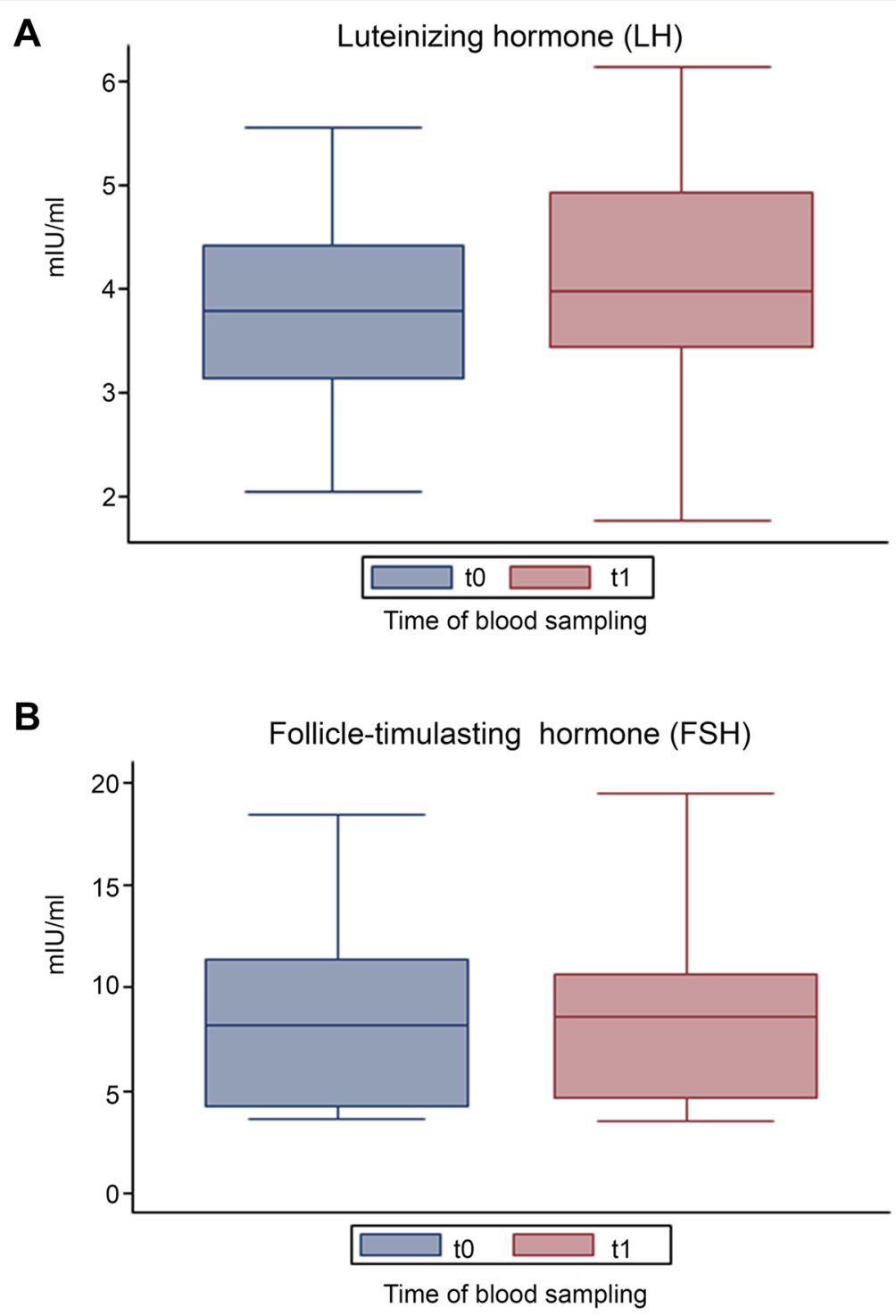

Fig. 8 Effect of D-chiro-inositol (DCl) treatment on Luteinizing hormone (LH) and follicle-stimulating hormone (FSH) levels. LH and FSH levels from 10 male volunteers at baseline (t0) and after 30 days of treatment (t1) with $1 \mathrm{~g} \mathrm{DCl}$ per day are presented as median values of (a) LH and (b) FSH levels (box plots) (LH, $p=0.3340 ; \mathrm{FSH}, p=0.5566$; Wilcoxon signed rank sum test). Symbol explanation: see caption of Fig. $1 \mathrm{a}$

able to reduce hepatic gluconeogenesis and endogenous glucose consumption, not only in human HepG2 cells but also in insulin-resistant mice. The decreased gluconeogenesis accounts for DCI-induced lowering of blood glucose levels and amelioration of glucose homeostasis and insulin resistance (IR) [67]. Such finding increased the number of different mechanisms through which DCI counteracts peripheral IR, observed also in other experimental models where IR was induced by glucosamine [68]. To date, little attention has been devoted to the dosage and the length of treatment, in order to avoid counterproductive effects on the hormonal level such as androgen increase $[38,39,69]$, which is especially harmful for PCOS patients. Currently, many authors agree that treatment with the sole DCI is inappropriate in such cases. On the contrary, DCI down-regulation activity on aromatase could be an interesting therapeutic opportunity in males, where $\mathrm{T}$ accumulation within certain limits is beneficial. Indeed, as reported in several studies, different ratios among sex hormones characterize male and female sexual spheres [70]. Estrogens, androgens and aromatase expression are fundamental in men, just like in women. Some authors reported the importance of low levels of estrogens in men, particularly for modulating libido, erectile function, and spermatogenesis [71]. In this regard, a correct T/E2 ratio should be equal to or greater than 10. Abnormal T/E2 $(<10)$ is associated with decreased semen parameters, and administration of an 


\section{$\mathrm{DCl}$ concentration}

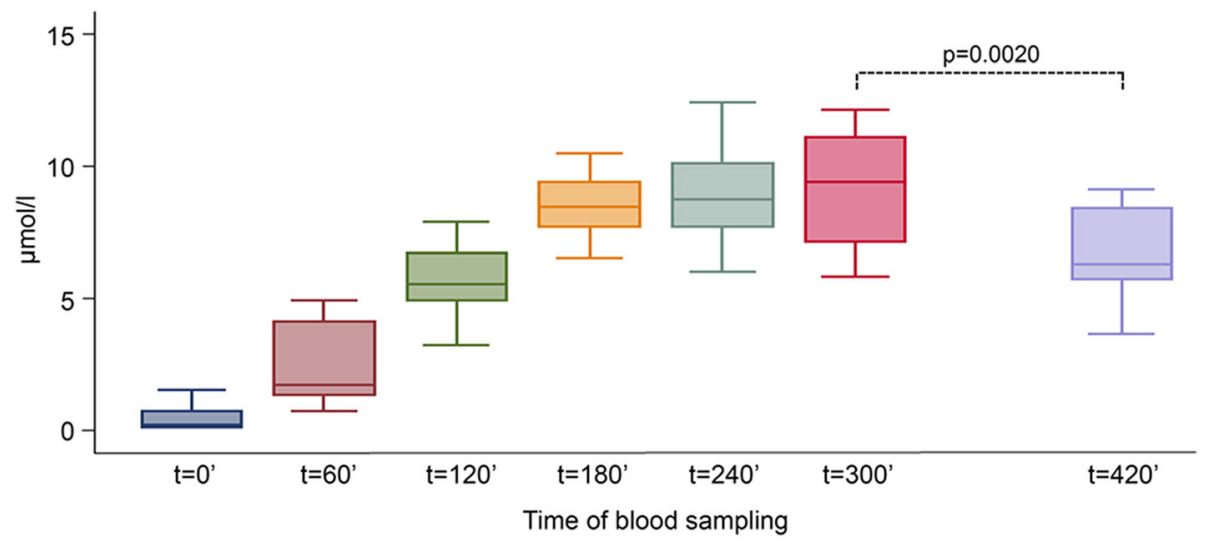

Fig. 9 D-chiro-inositol (DCl) pharmacokinetics. DCl concentration ( $\mu \mathrm{mol} / \mathrm{l})$ in serum from 10 male volunteers at different time points after oral administration of $1 \mathrm{~g} \mathrm{DCl}$ (single dose). Median values of DCl at different time points after oral administration are reported (Cmax: $9.40 \mathrm{\mu mol} / \mathrm{l}$, Tmax: $240 \mathrm{~min}$, AUC (0-420): 2750.59). After $420 \mathrm{~min}, \mathrm{DCl}$ concentration is significantly decreased in comparison to $300 \mathrm{~min}(p=0.0020)$. Symbol explanation: see caption of Fig. 1a

aromatase inhibitor proved to normalize such alterations, yielding to improved sperm concentration, motility, and morphology [71].

Considering its effects on sex hormone balance and its safety profile [42-48, 63], DCI can cover new therapeutic opportunities. DCI may be administered to male patients with "mild hypogonadism", characterized by low levels of $\mathrm{T}$ due to conditions such as hypogonadal and senile hypogonadism, both sexual dysfunctions that need androgen levels to be rebalanced [40, 41].

As previously pointed out, although our results are obtained in males, they can provide suggestions also for therapies in females. Indeed, DCI should be tested in the treatment of hyper-estrogenic conditions, such as endometriosis, and breast and endometrial cancer [40, 41]. Furthermore, administration of DCI, either alone or in combination with aromatase inhibitors (e.g., letrozole, anastrozole, or exemestane) to decrease their dosage, might induce ovulation in some kind of patients [40, 41]. In any case, the length of DCI treatment, as well as its

Table 2 D-chiro-inositol (DCl) and myo-inositol (MI) in blood at baseline and after 30 days DCI treatment in volunteers V1-V10

\begin{tabular}{lllll}
\hline Time & Percentile & $\mathbf{D C l} \boldsymbol{\mu \mathrm { mol } / \mathbf { I }}$ & $\mathbf{M I} \boldsymbol{\mu m o l} / \mathbf{l}$ & $\mathbf{M I} / \mathbf{D C l}$ \\
\hline t0 & 25 & 0.18 & 14.5 & $44: 1$ \\
& $\mathbf{5 0}$ & $\mathbf{0 . 3 9}$ & $\mathbf{1 7 . 2}$ & \\
& 75 & 0.71 & 20.8 & \\
t1 & 25 & 12.5 & 18.4 & $1.5: 1$ \\
& $\mathbf{5 0}$ & $\mathbf{1 5 . 2}$ & $\mathbf{2 2 . 5}$ & \\
& 75 & 18.7 & 25.9 & \\
\hline
\end{tabular}

Results of $D C I$ D-chiro-inositol, $M I$ myo-inositol and $\mathrm{MI} / \mathrm{DCl}$ ratio at baseline (t0) and after DCl treatment (t1) expressed as Percentiles (25, 50 and 75$)$ for 10 volunteers (V1-V10) dosage needs to be carefully evaluated for each pathology to avoid unintended effects.

\section{Conclusions}

The preliminary results presented in this report demonstrate, for the first time, that a daily oral administration of $1 \mathrm{~g}$ DCI can improve the sexual hormone profile in adult men. As result of DCI treatment, E1 significantly and E2 not significantly decreased, whereas T, DHEAS and Epia increased, resulting in increased T/E2 ratio. The most dramatic change was the significant reduction of E1 serum levels, which may relate to a the direct hypoglycemic activity previously observed for DCI. Altogether, these findings lead the authors to propose that DCI may act as a down-regulator of the aromatase activity. Additional studies with a larger cohort of patients are required to confirm our findings, but also to evaluate the effects on prostate and sperm parameters and to understand the underlying molecular mechanisms involved in DCI activities. A relevant aspect to highlight is the safety profile of DCI, which represents a great advantage with respect to aromatase inhibitors.

The complex activities exerted by DCI offer promising opportunities. DCI may be administered at different dosages and length of treatment to treat in men mood disorders or reduced libido associated to low testosterone levels, hypogonadotropic hypogonadism, overweight or obesity.

\footnotetext{
Abbreviations

A4: Androstenedione; Als: Aromatase inhibitors; AUC: Area under the curve; BMI: Body mass index; Cmax: Maximum concentration recorded; CYP19A1: Aromatase gene; DCl: D-chiro-inositol; DHEA

S: Dehydroepiandrosterone sulfate; E2: Estradiol; E1: Estrone; ELISA: Enzymelinked immunosorbent assay; Epia: Epiandrosterone; FSH: Follicle-stimulating hormone; FOXO1: Forkhead transcription factor 1; HOMA: Homeostatic
} 
Model Assessment; IPGs: Inositol phosphoglycans; IR: Insulin resistance; LH: Luteinizing hormone; MI: Myo-inositol; PI3K: Phosphatidylinositol 3-kinase; PCOS: Polycystic Ovary Syndrome; AKT: Protein kinase B; t0: Baseline time; t1: Post-DCl treatment time; T: Testosterone; T2DM: Type 2 Diabetes Mellitus; Tmax: Time required to reach Cmax; V1-V10: Volunteers 1 to 10

\section{Acknowledgements}

The authors wish to thank Dr. Orietta Picconi for her contribution in the statistical analysis.

\section{Authors' contributions}

GM and VU conceived and organized the study, GM, MSBE and GB carried out the study, GM, VU, MVL and ASL analysed and discussed the data, GM and MVL supervised the statistical procedures and wrote the paper. All authors contributed to the critical revisions of the manuscript and all authors approved and authorized the final version.

\section{Funding}

This work was supported by LoLiPharma srl (Rome, Italy).

\section{Availability of data and materials}

The data generated or analysed during this study are included in this published article. Further information can be obtained from the Corresponding Author

\section{Declarations}

\section{Ethics approval and consent to participate}

This study was approved by the Local Ethics Committee of Alma Res Fertility Center in Rome (registration n. 005/2020). The volunteers enrolled in the study provided their written informed consent to participate.

\section{Consent for publication}

Consent for publication was retrieved from the volunteers and is available.

\section{Competing interests}

Vittorio Unfer is an employee at Lo.Li. Pharma srl. (Rome, Italy). The other authors have no conflict of interest to disclose.

\section{Author details}

${ }^{1}$ Systems Biology Group Lab, Rome, Italy. ${ }^{2}$ Experts Group on Inositols in Basic and Clinical Research (EGOI), Rome, Italy. ${ }^{3}$ Instituto de Biología y Medicina Experimental (IBYME, CONICET-FIBYME). Consejo Nacional de Investigaciones Científicas y Técnicas de Argentina (CONICET), Buenos Aires, Argentina. ${ }^{4}$ Alma Res Fertility Center, Rome, Italy. ${ }^{5}$ Department of Obstetrics and Gynecology, "Filippo Del Ponte" Hospital, University of Insubria, Varese, Italy.

\section{Received: 3 February 2021 Accepted: 11 April 2021}

\section{Published online: 03 June 2021}

\section{References}

1. Benyi E, Savendahl L. The physiology of childhood growth: hormonal regulation. Horm Res Paediatr. 2017;88(1):6-14. https://doi.org/10.1159/0004 71876.

2. Falahati-Nini A, Riggs BL, Atkinson EJ, O'Fallon WM, Eastell R, Khosla S. Relative contributions of testosterone and estrogen in regulating bone resorption and formation in normal elderly men. J Clin Invest. 2000;106(12): 1553-60. https://doi.org/10.1172/JCl10942

3. Vermeulen A, Kaufman JM, Goemaere S, van Pottelberg I. Estradiol in elderly men. Aging Male. 2002;5(2):98-102. https://doi.org/10.1080/tam.5.2.98.102.

4. Meeker JD, Singh NP, Hauser R. Serum concentrations of estradiol and free $\mathrm{T} 4$ are inversely correlated with sperm DNA damage in men from an infertility clinic. J Androl. 2008;29(4):379-88. https://doi.org/10.2164/jandrol.1 07.004416 .

5. Muller M, den Tonkelaar I, Thijssen JH, Grobbee DE, van der Schouw YT. Endogenous sex hormones in men aged 40-80 years. Eur J Endocrinol. 2003;149(6):583-9. https://doi.org/10.1530/eje.0.1490583.

6. Muller M, van der Schouw YT, Thijssen JH, Grobbee DE. Endogenous sex hormones and cardiovascular disease in men. J Clin Endocrinol Metab. 2003;88(11):5076-86. https://doi.org/10.1210/jc.2003-030611.
7. Stocco C. Tissue physiology and pathology of aromatase. Steroids. 2012; 77(1-2):27-35. https://doi.org/10.1016/j.steroids.2011.10.013.

8. Harada N, Sasano H, Murakami H, Ohkuma T, Nagura H, Takagi Y. Localized expression of aromatase in human vascular tissues. Circ Res. 1999;84(11): 1285-91. https://doi.org/10.1161/01.RES.84.11.1285.

9. Larionov AA, Vasyliev DA, Mason Jl, Howie AF, Berstein LM, Miller WR. Aromatase in skeletal muscle. J Steroid Biochem Mol Biol. 2003;84(4):485-92. https://doi.org/10.1016/S0960-0760(03)00059-1.

10. Hata S, Miki Y, Saito R, Ishida K, Watanabe M, Sasano H. Aromatase in human liver and its diseases. Cancer Med. 2013;2(3):305-15. https://doi.org/1 $0.1002 /$ cam4.85

11. Kobayashi H, Yoshida S, Shirasawa N, Maeda K, Naito A. Expression and localization of aromatase in human gastric mucosa : Immunohistochemical study using biopsy materials. Histochem Cell Biol. 2019;151(1):21-8. https:// doi.org/10.1007/s00418-018-1708-3.

12. Cleland WH, Mendelson CR, Simpson ER. Aromatase activity of membrane fractions of human adipose tissue stromal cells and adipocytes. Endocrinology. 1983;113(6):2155-60. https://doi.org/10.1210/endo-113-6-2155.

13. Cooke PS, Nanjappa MK, Ko C, Prins GS, Hess RA. Estrogens in male physiology. Physiol Rev. 2017;97(3):995-1043. https://doi.org/10.1152/ physrev.00018.2016.

14. Blakemore J, Naftolin F. Aromatase: contributions to physiology and disease in women and men. Physiology (Bethesda). 2016;31(4):258-69. https://doi. org/10.1152/physiol.00054.2015.

15. Wu FC, Tajar A, Pye SR, Silman AJ, Finn JD, O'Neill TW, et al. Hypothalamicpituitary-testicular axis disruptions in older men are differentially linked to age and modifiable risk factors: the European male aging study. J Clin Endocrinol Metab. 2008;93(7):2737-45. https://doi.org/10.1210/jc.2007-1972.

16. Feldman HA, Longcope C, Derby CA, Johannes CB, Araujo AB, Coviello AD, et al. Age trends in the level of serum testosterone and other hormones in middle-aged men: longitudinal results from the Massachusetts male aging study. J Clin Endocrinol Metab. 2002;87(2):589-98. https://doi.org/10.1210/ jcem.87.2.8201.

17. Cleland $\mathrm{WH}$, Mendelson CR, Simpson ER. Effects of aging and obesity on aromatase activity of human adipose cells. J Clin Endocrinol Metab. 1985; 60(1):174-7. https://doi.org/10.1210/jcem-60-1-174.

18. Araujo AB, O'Donnell AB, Brambilla DJ, Simpson WB, Longcope C, Matsumoto AM, et al. Prevalence and incidence of androgen deficiency in middle-aged and older men: estimates from the Massachusetts male aging study. J Clin Endocrinol Metab. 2004;89(12):5920-6. https://doi.org/10.1210/ jc.2003-031719.

19. Harman SM, Metter EJ, Tobin JD, Pearson J, Blackman MR. Baltimore longitudinal study of a. longitudinal effects of aging on serum total and free testosterone levels in healthy men. Baltimore longitudinal study of aging. J Clin Endocrinol Metab. 2001;86(2):724-31. https://doi.org/10.1210/ jcem.86.2.7219.

20. Mulligan T, Frick MF, Zuraw QC, Stemhagen A, McWhirter C. Prevalence of hypogonadism in males aged at least 45 years: the HIM study. Int J Clin Pract. 2006;60(7):762-9. https://doi.org/10.1111/j.1742-1241.2006.00992.x.

21. Amory JK, Watts NB, Easley KA, Sutton PR, Anawalt BD, Matsumoto AM, et al. Exogenous testosterone or testosterone with finasteride increases bone mineral density in older men with low serum testosterone. J Clin Endocrinol Metab. 2004;89(2):503-10. https://doi.org/10.1210/jc.2003-031110.

22. Corona G, Monami M, Rastrelli G, Aversa A, Sforza A, Lenzi A, et al. Type 2 diabetes mellitus and testosterone: a meta-analysis study. Int J Androl. 2011; 34(6 Pt 1):528-40. https://doi.org/10.1111/j.1365-2605.2010.01117.x.

23. Corona G, Rastrelli G, Di Pasquale G, Sforza A, Mannucci E, Maggi M. Testosterone and cardiovascular risk: meta-analysis of interventional studies. J Sex Med. 2018;15(6):820-38. https://doi.org/10.1016/j.jsxm.2018.04.641.

24. Snyder PJ, Ellenberg SS, Farrar JT. Testosterone treatment in older men. N Engl J Med. 2016;375(1):90. https://doi.org/10.1056/NEJMc1603665.

25. Resnick SM, Matsumoto AM, Stephens-Shields AJ, Ellenberg SS, Gill TM, Shumaker SA, et al. Testosterone treatment and cognitive function in older men with low testosterone and age-associated memory impairment. JAMA. 2017;317(7):717-27. https://doi.org/10.1001/jama.2016.21044.

26. Brock G, Heiselman D, Maggi M, Kim SW, Rodriguez Vallejo JM, Behre HM, et al. Effect of testosterone solution 2\% on testosterone concentration, sex drive and energy in Hypogonadal men: results of a placebo controlled study. J Urol. 2016;195(3):699-705. https://doi.org/10.1016/j.juro.2015.10.083.

27. Grossmann M, Hoermann R, Wittert G, Yeap BB. Effects of testosterone treatment on glucose metabolism and symptoms in men with type 2 
diabetes and the metabolic syndrome: a systematic review and metaanalysis of randomized controlled clinical trials. Clin Endocrinol. 2015;83(3): 344-51. https://doi.org/10.1111/cen.12664.

28. Basaria S, Coviello AD, Travison TG, Storer TW, Farwell WR, Jette AM, et al. Adverse events associated with testosterone administration. N Engl J Med. 2010;363(2):109-22. https://doi.org/10.1056/NEJMoa1000485.

29. Baillargeon J, Urban RJ, Morgentaler A, Glueck CJ, Baillargeon G, Sharma G, et al. Risk of venous thromboembolism in men receiving testosterone therapy. Mayo Clin Proc. 2015;90(8):1038-45. https://doi.org/10.1016/j.ma yocp.2015.05.012.

30. Martinez C, Suissa S, Rietbrock S, Katholing A, Freedman B, Cohen AT, et al. Testosterone treatment and risk of venous thromboembolism: population based case-control study. BMJ. 2016;355:i5968.

31. de Ronde W, de Jong FH. Aromatase inhibitors in men: effects and therapeutic options. Reprod Biol Endocrinol. 2011;9(1):93. https://doi.org/1 0.1186/1477-7827-9-93

32. Kalkanli A, Akdere H, Cevik G, Salabas E, Cilesiz NC, Kadioglu A. Hypergonadotropic Hypogonadism: Management Of Infertility. Curr Pharm Des. 2021;27(8):1-6.

33. Khosrow-Khavar F, Filion KB, Bouganim N, Suissa S, Azoulay L. Aromatase inhibitors and the risk of cardiovascular outcomes in women with breast Cancer: a population-based cohort study. Circulation. 2020;141(7):549-59. https://doi.org/10.1161/CIRCULATIONAHA.119.044750

34. Bizzarri M, Fuso A, Dinicola S, Cucina A, Bevilacqua A. Pharmacodynamics and pharmacokinetics of inositol(s) in health and disease. Expert Opin Drug Metab Toxicol. 2016;12(10):1181-96. https://doi.org/10.1080/17425255.201 6.1206887.

35. Pak Y, Huang LC, Lilley KJ, Larner J. In vivo conversion of [3H] myoinositol to [3H] chiroinositol in rat tissues. J Biol Chem. 1992;267(24):16904-10. https:// doi.org/10.1016/S0021-9258(18)41870-4.

36. Larner J. D-chiro-inositol--its functional role in insulin action and its deficit in insulin resistance. Int J Exp Diabetes Res. 2002;3(1):47-60. https://doi.org/1 $0.1080 / 15604280212528$

37. Larner J, Brautigan DL, Thorner MO. D-chiro-inositol glycans in insulin signaling and insulin resistance. Mol Med. 2010;16(11-12):543-52. https:// doi.org/10.2119/molmed.2010.00107.

38. Nestler JE, Jakubowicz DJ, de Vargas AF, Brik C, Quintero N, Medina F. Insulin stimulates testosterone biosynthesis by human thecal cells from women with polycystic ovary syndrome by activating its own receptor and using inositolglycan mediators as the signal transduction system. J Clin Endocrinol Metab. 1998;83(6):2001-5. https://doi.org/10.1210/jcem.83.6.4886.

39. Sacchi S, Marinaro F, Tondelli D, Lui J, Xella S, Marsella T, et al. Modulation of gonadotrophin induced steroidogenic enzymes in granulosa cells by $\mathrm{d}$ chiroinositol. Reprod Biol Endocrinol. 2016;14(1):52. https://doi.org/10.1186/ s12958-016-0189-2

40. Lagana AS, Unfer V. D-Chiro-Inositol's action as aromatase inhibitor: rationale and potential clinical targets. Eur Rev Med Pharmacol Sci. 2019; 23(24):10575-6. https://doi.org/10.26355/eurrev_201912_19752.

41. Lagana AS, Garzon S, Unfer V. New clinical targets of d-chiro-inositol: rationale and potential applications. Expert Opin Drug Metab Toxicol. 2020; 16(8):703-10. https://doi.org/10.1080/17425255.2020.1785429.

42. Ku BJ, Kim HJ, Park KS. The clinical study to evaluate the safety and efficacy of D-chiro-inositol in patients with type 2 diabetes. J Korean Intern Med. 2007;72(1):29-36

43. Maurizi AR, Menduni M, Del Toro R, Kyanvash S, Maggi D, Guglielmi C, et al. A pilot study of D-chiro-inositol plus folic acid in overweight patients with type 1 diabetes. Acta Diabetol. 2017;54(4):361-5. https://doi.org/10.1007/ s00592-016-0954-X.

44. Nestler JE, Jakubowicz DJ, Reamer P, Gunn RD, Allan G. Ovulatory and metabolic effects of D-chiro-inositol in the polycystic ovary syndrome. N Engl J Med. 1999;340(17):1314-20. https://doi.org/10.1056/NEJM199904293401703.

45. Lagana AS, Barbaro L, Pizzo A. Evaluation of ovarian function and metabolic factors in women affected by polycystic ovary syndrome after treatment with D-Chiro-inositol. Arch Gynecol Obstet. 2015;291(5):1181-6. https://doi. org/10.1007/s00404-014-3552-6

46. Cianci A, Panella M, Fichera M, Falduzzi C, Bartolo M, Caruso S. D-chiroinositol and alpha lipoic acid treatment of metabolic and menses disorders in women with PCOS. Gynecol Endocrinol. 2015;31(6):483-6. https://doi. org/10.3109/09513590.2015.1014784.

47. Fruzzetti F, Capozzi A, Canu A, Lello S. Treatment with d-chiro-inositol and alpha lipoic acid in the management of polycystic ovary syndrome. Gynecol
Endocrinol. 2019;35(6):506-10. https://doi.org/10.1080/09513590.2018.154 0573.

48. Artini PG, Obino MER, Micelli E, Malacarne E, Vacca C, Papini F, et al. Effect of d-chiro-inositol and alpha-lipoic acid combination on $\mathrm{COH}$ outcomes in overweight/obese PCOS women. Gynecol Endocrinol. 2020;36(9):755-9. https://doi.org/10.1080/09513590.2020.1737007.

49. Aschenbrenner DS. Serious adverse effects of testosterone abuse. Am J Nurs. 2017;117(2):20-1.

50. Jiang J, Tang NL, Ohlsson C, Eriksson AL, Vandenput L, Chan FW, et al. Association of genetic variations in aromatase gene with serum estrogen and estrogen/testosterone ratio in Chinese elderly men. Clin Chim Acta. 2010;411(1-2):53-8. https://doi.org/10.1016/j.cca.2009.09.039.

51. Monastra G, Sambuy Y, Ferruzza S, Ferrari D, Ranaldi G. Alpha-lactalbumin effect on Myo-inositol intestinal absorption: in vivo and in vitro. Curr Drug Deliv. 2018:15(9):1305-11. https://doi.org/10.2174/1567201815666180509102 641.

52. Calogero AE, Gullo G, La Vignera S, Condorelli RA, Vaiarelli A. Myoinositol improves sperm parameters and serum reproductive hormones in patients with idiopathic infertility: a prospective double-blind randomized placebocontrolled study. Andrology. 2015;3(3):491-5. https://doi.org/10.1111/andr.12 025.

53. Barbotin AL, Ballot C, Sigala J, Ramdane N, Duhamel A, Marcelli F, et al. The serum inhibin B concentration and reference ranges in normozoospermia. Eur J Endocrinol. 2015;172(6):669-76. https://doi.org/10.1530/EJE-14-0932.

54. Condorelli RA, Barbagallo F, Calogero AE, Cannarella R, Crafa A, La Vignera S. D-Chiro-Inositol Improves Sperm Mitochondrial Membrane Potential: In Vitro Evidence. J Clin Med. 2020;9(5):1-7.

55. Artini PG, Casarosa E, Carletti E, Monteleone P, Di Noia A, Di Berardino OM. In vitro effect of myo-inositol on sperm motility in normal and oligoasthenospermia patients undergoing in vitro fertilization. Gynecol Endocrinol. 2017;33(2):109-12. https://doi.org/10.1080/09513590.2016.12541 79.

56. Condorelli RA, Calogero AE, La Vignera S. Hyperestrogenism and low serum testosterone-17beta-estradiol ratio are associated with non-bacterial male accessory gland inflammation. Int J Immunopathol Pharmacol. 2016;29(3): 488-93. https://doi.org/10.1177/0394632016644446.

57. Sun S, Jiao M, Han C, Zhang Q, Shi W, Shi J, et al. Causal Effects of Genetically Determined Metabolites on Risk of Polycystic Ovary Syndrome: A Mendelian Randomization Study. Front Endocrinol (Lausanne). 2020;11: 621.

58. Jasuja GK, Travison TG, Davda M, Rose AJ, Zhang A, Kushnir MM, et al. Circulating estrone levels are associated prospectively with diabetes risk in men of the Framingham heart study. Diabetes Care. 2013;36(9):2591-6. https://doi.org/10.2337/dc12-2477.

59. Barros RP, Gustafsson JA. Estrogen receptors and the metabolic network Cell Metab. 2011;14(3):289-99. https://doi.org/10.1016/j.cmet.2011.08.005.

60. Foryst-Ludwig A, Kintscher U. Metabolic impact of estrogen signalling through ERalpha and ERbeta. J Steroid Biochem Mol Biol. 2010;122(1-3):7481. https://doi.org/10.1016/j.jsbmb.2010.06.012.

61. Nagamani M, Szymajda A, Sepilian V, Urban RJ, Gilkison C. Effects of raloxifene on insulin sensitivity, beta-cell function, and hepatic insulin extraction in normal postmenopausal women. Fertil Steril. 2008;89(3):614-9. https://doi.org/10.1016/j.fertnstert.2007.03.083.

62. Lagana AS, Garzon S, Casarin J, Franchi M, Ghezzi F. Inositol in polycystic ovary syndrome: restoring fertility through a pathophysiology-based approach. Trends Endocrinol Metab. 2018;29(11):768-80. https://doi.org/10.1 016/j.tem.2018.09.001.

63. Milewska EM, Czyzyk A, Meczekalski B, Genazzani AD. Inositol and human reproduction. From cellular metabolism to clinical use. Gynecol Endocrinol. 2016;32(9):690-5. https://doi.org/10.1080/09513590.2016.1188282.

64. Bevilacqua A, Dragotto J, Giuliani A, Bizzarri M. Myo-inositol and D-chiroinositol (40:1) reverse histological and functional features of polycystic ovary syndrome in a mouse model. J Cell Physiol. 2019;234(6):9387-98. https://doi. org/10.1002/jcp.27623.

65. Nordio M, Basciani S, Camajani E. The 40:1 myo-inositol/D-chiro-inositol plasma ratio is able to restore ovulation in PCOS patients: comparison with other ratios. Eur Rev Med Pharmacol Sci. 2019;23(12):5512-21. https://doi. org/10.26355/eurrev_201906_18223.

66. Facchinetti F, Appetecchia M, Aragona C, Bevilacqua A, Bezerra Espinola MS, Bizzarri $M$, et al. Experts' opinion on inositols in treating polycystic ovary syndrome and non-insulin dependent diabetes mellitus: a further help for 
human reproduction and beyond. Expert Opin Drug Metab Toxicol. 2020; 16(3):255-74. https://doi.org/10.1080/17425255.2020.1737675.

67. Cheng F, Han L, Xiao Y, Pan C, Li Y, Ge X, et al. D- chiro-inositol ameliorates high fat diet-induced hepatic Steatosis and insulin resistance via PKCepsilon-PI3K/AKT pathway. J Agric Food Chem. 2019;67(21):5957-67. https://doi.org/10.1021/acs.jafc.9b01253.

68. Yoshino K, Takeda N, Sugimoto M, Nakashima K, Okumura S, Hattori J, et al. Differential effects of troglitazone and D-chiroinositol on glucosamineinduced insulin resistance in vivo in rats. Metabolism. 1999;48(11):1418-23. https://doi.org/10.1016/50026-0495(99)90153-1.

69. Nestler JE. Regulation of the aromatase activity of human placental cytotrophoblasts by insulin, insulin-like growth factor-I, and -II. J Steroid Biochem Mol Biol. 1993;44(4-6):449-57. https://doi.org/10.1016/09600760(93)90249-V.

70. Hines M. Sex-related variation in human behavior and the brain. Trends Cogn Sci. 2010;14(10):448-56. https://doi.org/10.1016/j.tics.2010.07.005.

71. Schulster M, Bernie AM, Ramasamy R. The role of estradiol in male reproductive function. Asian J Androl. 2016;18(3):435-40. https://doi.org/1 0.4103/1008-682X.173932.

\section{Publisher's Note}

Springer Nature remains neutral with regard to jurisdictional claims in published maps and institutional affiliations.

Ready to submit your research? Choose BMC and benefit from:

- fast, convenient online submission

- thorough peer review by experienced researchers in your field

- rapid publication on acceptance

- support for research data, including large and complex data types

- gold Open Access which fosters wider collaboration and increased citations

- maximum visibility for your research: over $100 \mathrm{M}$ website views per year

At BMC, research is always in progress.

Learn more biomedcentral.com/submissions 